\title{
Conditions Under Which Québec Prefers a Strong Federal Government, or Why Decentralization is not Necessarily a Good Thing for Québec
}

\section{Michel Venne*}

Let me begin by thanking the organizers of a Simon Fraser University federalism workshop for inviting a non-academic to share some reflections about federalism. ${ }^{1}$ This file cannot stay closed forever. While preparing these reflections, I came across a lapel pin representing the fleur de lisé - the Québec flag - which illustrates one of the main points I want to stress here: the Québec question is essentially a question of identity and recognition. It has little or nothing to do with the so-called fiscal imbalance or any other specific problem of that kind.

It has often been written that the Québec nation is not free within Canada. If a Vancouver audience were to pose the question of what Québec wants, the easy answer would be to be recognized for what it is, and to be as free as possible to decide for itself what is good for the Québécois people. This is what Mr. Mario Dumont, leader of the Action démocratique du Québec (ADQ), calls "autonomy." This is what Paul Gérin-Lajoie meant in his 1966 report to the Québec Liberal Party calling for the recognition of "special status" for Québec. This is also what Unionist premier Daniel Johnson, Sr., had in mind in 1968 when he posed two federalist options for Québec: "Equality or Independence." And this is also the reason why Robert Bourassa refused to sign the Victoria Charter in
1970. More recently, recognizing Québec as a "distinct society" was the essence of the Meech Lake Accord of 1987.

Important distinctions need to be made. We are not talking here of a decentralized federation. Québec has been saying for a long time that it wants to be treated as an equal partner by so-called English Canada or the "Rest of Canada" (ROC). Québec does not want to be merely a province like all the others. This is not all rhetoric; it is profoundly felt by a majority of Québécois, and it is based on the principle of the equality of the imagined "two founding peoples" of Canada. Apologies are due here to First Nations peoples.

The desire to be recognized as a special entity within the Canadian federation came out clearly in the electoral platform of the ADQ in the 2007 provincial election. ${ }^{2}$ The ADQ seeks autonomy for Québec without separation. It proposes to abolish the Council of the Federation and to replace multilateral executive federalism (as it has been practiced until now) with equal, "nation to nation" bilateral relations between Québec and Canada. Québec would then adopt a constitution and would no longer be formally referred to as a province. Officially, the Québec constitution would adopt the term "Autonomist State of 
Québec" ("l'État autonome du Québec"). ${ }^{3}$ Québec citizenship, and other features of statehood, would accompany this constitutional status. It is not clear that all of this would change much in the daily lives of the people, if this project were to be implemented. Moreover, if the ADQ were to win an election, and if it tried to implement this platform, it would probably be faced with the harsh reality that it is not possible to act as if you are sovereign when you are not! In any event, Mr. Dumont is a popular political leader in Québec, and this has at least something to do with his "autonomist" position (located between federalist and sovereigntist options).

Autonomy, for Mr. Dumont and for many Québécois who support the idea, is a way to have your cake and eat it too: it is s'affirmer sans se séparer. Mr. Dumont seeks thereby to achieve autonomy for the Québec nation without separating from Canada. Many Québécois have felt unfairly treated and alienated by English Canadians. But, they still believe that this could be fixed, if I can put it this way, by remaining within Canada. The Québécois prefer "réparation" to "séparation," and they still believe it is achievable by amending the Canadian Constitution. They suppose that a constitutional amendment which entrenches recognition of Québec in the fundamental law of the country would give it more power, and greater political and financial autonomy within Canada.

The problem with this vision is that, since 1982, it has become very difficult to achieve. As a result of the process that led to the patriation of the Constitution, including two reference cases decided by the Supreme Court of Cana$\mathrm{da}$, all provinces are now considered equal. The Canadian Constitution cannot be amended without the consent of at least seven provinces, and the equality of the two imagined founding peoples is now recognized only with respect to the status of official languages. In the 1998 Québec secession reference, ${ }^{4}$ the Supreme Court of Canada identified four relevant constitutional principles; duality (or if you prefer, the recognition of two founding peoples) was not one of them. But the protection of minority rights was indeed one of these principles. French Canadians have rights as members of a language mi- nority in Canada, but not as a founding people. Again, Québec does not have special status in the federation; it is a province like all the others, and that's all.

Admittedly, forms of federal asymmetry have developed over time in Canada. But as Peter Graefe of McMaster University has written, ${ }^{5}$ recent examples such as the September 2004 Federal-Provincial-Territorial Health Accord, are quite limited in scope compared to the experience of the 1960s and 1970s, when Québec created its own pension plan, negotiated a specific agreement on immigration, and opted-out of many federal programs. For Graefe, asymmetry was seen as acceptable to the federal government in 2004 because it was consistent with an emerging new form of governance. The federal government, Graefe writes, is less concerned with ensuring that provinces adhere to strict conditions or broader national standards, and more interested in setting agendas and steering reform. In such a context, Ottawa accepts asymmetry as provincial variation in program design at a low cost. Graefe notes that this new governance-style does not require the same degree of provincial buy-in as the major programs of the Canadian welfare state, which emerged in the 1950s and 1960s. Nevertheless, the new asymmetry allows the federal government to participate in re-engineering the content, delivery, and goals of programs within provincial jurisdiction, even while the federal government's share of total program costs generally remain less than it was in the late 1970s or early 1980s.

The spirit of the 1999 Social Union Framework Agreement - which Québec refused to sign - is present in recent agreements, especially those addressing health care, and includes those signed by separatist premiers Lucien Bouchard and Bernard Landry. These supposedly asymmetrical accords are, in fact, offered to all provinces, and Québec gains no special status from signing-on to them. Because they are offered to all provinces, they are easier to sell in ROC than would be constitutional recognition of special status for Québec. The recent House of Commons motion recognizing "Québécois as a nation within a united Canada" is not entrenched in the Constitution. This mo- 
tion, in any case, will probably be of no more consequence than was the House of Common's recognition of Québec as a "distinct society" at the end of 1995, a couple of weeks after the Québec secession referendum.

Special status for Québec is no longer possible in the post-Meech era. A poll conducted by the CBC, only six months after the 1995 referendum, showed that four out of ten Canadians outside Québec would have preferred that Québec become independent rather than be given more or new powers. In other words, 40 percent of Canadians outside Québec would rather Québec leave than be offered concessions, and 85 percent were against special powers for Québec. Notably, this was only six months after a referendum in which close to 50 percent of Québécois said they wanted to create a new country. In other words, even the threat of secession was not enough to sway public opinion in ROC towards the concession of special status for Québec in Canada's federation. ${ }^{6}$

The Québec autonomy that Mario Dumont is promising is no more than an illusion. It will never happen. At the same time, the federal asymmetry we actually have with Québec is without real consequence. According to a study by Gilbert Charland ${ }^{7}$ of the École nationale d'administration publique, Ottawa has intruded into thirteen of sixteen policy domains under exclusive provincial jurisdiction. The only three remaining domains still under exclusive provincial jurisdiction are municipal affairs, primary and secondary education, and civil law. Québec's fiscal policy is intertwined with federal fiscal policy as, of course, is the case with all other provinces. In the early 1990s, about 21 percent of the Québec government's revenues came from federal transfers; in 2006, that number dropped to 18 percent, although Ottawa promised to increase that contribution in its next budget. Undoubtedly, it is difficult to talk of an autonomous Québec when it does not control foreign trade, monetary and economic policy, criminal law, and so many of the other important policy domains that John A. Macdonald made sure remained in the hands of the federal government.

Nevertheless, the fact remains that there are times when Québec sometimes agrees that the federal government should be strong, and that is when its actions or policies are consistent with the goals of Québec. When Ottawa put more money into the health care system, even the separatist Bernard Landry was unable to refuse it, despite the strings attached to the purse. There is also agreement within Québec on the need for Canada to fight for the adoption of an international convention to protect the diversity of cultural expression. Québec supports the use of the Canada Health Act ${ }^{8}$ to protect the public character of the health care system. And Québec had no objection when former Liberal cabinet minister Ken Dryden tried to get other provinces on board with the idea of low-cost childcare, with financial compensation for Québec. In spite of these counter-examples, Québec prefers to retain its capacity to make policy decisions for itself, by itself. Sometimes Québec goes it alone, as it did when it created a childcare system costing about $\$ 2$ billion a year, and without any financial support from Ottawa. In fact, Québec is even prepared to lose hundreds of millions of dollars in tax benefits for Québec taxpayers who pay only $\$ 5$ or $\$ 7$ a day for daycare, instead of the $\$ 30$ or more paid by parents in other provinces. When Québec decides to go it alone with a policy that is inconsistent with federal fiscal or budgetary priorities, the province loses money (as would be the case with any other province). To act autonomously and to innovate in an intertwined fiscal system comes at a price, and autonomy does not pay in the Canadian fiscal system as it now exists; social innovation does not come cheap. Real autonomy for a province, defined as more than mere variation in program design and delivery, is difficult to achieve in the Canadian federation. This is true for the poorer provinces, but it is probably also true for a rich province like Ontario.

So the reflex of Québec governments has long been to demand more power, but in the context of the federal norm of provincial equality, more power means further decentralization. Indeed, decentralization is a word frequently used to describe the traditional demands of Québec. But is decentralization a satisfactory answer to the question of Québec in the Canadian federation? Sometimes it can play against 
the interests and aspirations of Québec and the Québécois to have a decentralized federation. Two examples illustrate the dilemma involved.

The first concerns nonrenewable natural resources, which belong to the provinces. That constitutional fact accounts for the extraordinary growth of the Albertan economy. Indeed, the exploitation of the tar sands has created a dramatic gap between what Alberta and the other provinces can afford to spend on social programs. Because of the growth in its natural resource revenues, Alberta's fiscal capacity after equalization for 2007-08 is more than $\$ 11,000$ per capita, while the per capita fiscal capacity of the other nine provinces ranges between $\$ 6,200$ and $\$ 6,900 .^{9}$ When one also considers that Alberta is a debt-free zone, while other provinces pay billions in interest costs to service their provincial debts, the gap grows even wider. There is even no sales tax in Alberta, making private investment in Alberta all the more attractive. Meanwhile, without receiving any benefit from Alberta's favourable revenue position, Canadians in other provinces are burdened with sharing the costs to the environment of the Albertan petroleum industry. Unquestionably, Québec does not benefit at all from Alberta's exercise of its autonomy. According to a study published by Stuart Landon \& Bradford Reid of the University of Alberta, ${ }^{10}$ the centralization of revenues correlates with lower regional inequalities. What we observe today in the example of nonrenewable natural resource revenues is a decentralized provincial revenue situation exactly the opposite of the one which might help Canadians in all regions gain access to comparable public services at reasonably comparable levels of taxation.

The second example is postsecondary education. Until 1995, under the Established Programs Financing (EPF) scheme, the provinces were limited in their ability to use federal transfers targeted for postsecondary education for other purposes. But in 1995, then finance minister Paul Martin not only reduced the amount of all transfers but merged them into one larger package - the Canada Heath and Social Transfer program (CHST) - which gave more flexibility to the provinces in their use of these funds. More flexibility in how these funds could be used by the provinces was the tradeoff the federal government was willing to make in exchange for offering less money. Among the many consequences of the introduction of the CHST, I might mention the impact of this increased flexibility on the cost of university tuition fees across the provinces. Until 1995, tuition fees amounted to around 20 percent of university revenues. When more flexibility was given to the provinces in their financing of postsecondary education, tuition fees started to rapidly increase to the level that we know today. The message from Paul Martin was clear: the federal government will offer less money for universities in Canada, and the provinces will have to find other money elsewhere. And provinces did indeed find this money - in the pockets of students or their parents. The federal government encouraged parents to save money to pay the cost of their children's university education by creating the Registered Education Saving Plan (RESP). All provinces applied the scheme. In Québec, tuition fees are less than a third of what they are in the rest of the country. But right now the Québec government is under pressure to increase those fees to the level of the rest of the provinces. The autonomy given to the provinces in the specific case of postsecondary education, or, to put the point differently, the decentralization of provinces' capacity to make policy decisions regarding postsecondary education, has become a new national standard which Québec finds difficult to reject because, again, it will be fiscally disadvantaged if it does not follow the lead of other provinces.

As it turns out, decentralization is not at all a guarantee of more autonomy, or a guarantee of better benefits for Québec. Asymmetry, as it has evolved over the last several years, has had only marginal effects on Québec's ability to achieve autonomy, and does not change the power dynamic in Canadian federalism. In this rapport de force, Québec is losing: losing power or losing money.

On the one hand, the federal division of powers between Ottawa and the provinces assigns Ottawa almost unlimited powers to define policy priorities and to steer reforms. Sometimes Québec agrees with the reforms Ottawa proposes 
- as in the case of health care - and sometimes Québec disagrees and suffers the consequences, usually losing money. But more than that, the Québécois presence is diminishing in federal institutions because its demographic weight is declining. As a result, the influence of Québec on federal policy making is fading.

In the face of this fading policy influence, decentralization may not be the best solution for Québec, especially when decentralization gives more power to richer or "have" provinces. Decentralization can create a new set of standards for fiscal or social policy that is difficult for Québec to oppose. The Québec government's margin of maneuver is restricted by these factors, and so is its capacity to protect Québec's differences, not only in terms of culture and identity but also in the fields of economic and social policy.

This explains why Québec has always adopted an ambiguous attitude toward the Canadian Constitution, asking for special status but also trying to take advantage of the pragmatic functioning and weak institutionalization of executive federalism. Maybe it is the only way Québec can take advantage of a type of federalism in which political actors have a very important role to play. But please, do no call the results of this strategy autonomy. Québec's constitutional ambiguity has often been matched by cooperative effort elsewhere in the federation, but it is a cooperative effort in which Québec will be more and more in a minority position.

I believe that it worth undertaking more research on the impact of decentralization on Québec's capacity for autonomous policy making. At the very least, undertaking such research might illuminate the significant differences between an autonomous province (even if this province is called an "autonomous state" as Mario Dumont suggests) and a sovereign country.

\section{Notes}

* Directeur général, Institut du Nouveau Monde.

1 These comments were first presented 9 March 2007 at a workshop entitled "Common Ground? Renewing the Federal Partnership in Quebec and the West," Simon Fraser University, Vancouver,
B.C.

2 At the time of the workshop, a general election campaign was underway in Québec. The Action démocratique du Québec became the Official Opposition in the National Assembly on 26 March, just behind the Liberal minority government led by Mr. Jean Charest in popular vote. The Parti Québécois, which promised a third referendum on sovereignty as soon as possible, was third, showing the worse performance of its history.

3 "Au Québec, on passe à l'action," online: Action démocratique du Québec <http://www.adq. qc.ca/fileadmin/General/adq_fichiers_pdf/adq_ program_e.pdf $>$.

4 Reference re Secession of Quebec, 1998 CanLII 793 (S.C.C.).

5 "The Scope and Limits of Asymmetry in Recent Social Policy Agreements" Asymmetric Working Papers (2005), online: The Institute of Intergovernmental Relations <http://www. queensu.ca/iigr/working/archive/Asymmetric/ papers/10.pdf>.

6 Pierre O’Neill, “Sondage CROP-Radio-Canada: Le mur de l'incompréhension demeure impénétrable" Le Devoir (26 March 1996) A1.

7 "Comparaison des relations intergouvernementales au sein de quelques fédérations," L'État québécois en perspectives, Observatoire de l'administration publique (Québec, Winter 2007), online: École nationale d'administration publique $<$ http://netedit.enap.ca/etatquebecois/docs/pp/ intergouvernemental/a-pp-intergouv.pdf $>$.

8 R.S.C. 1985 , c. C-6.

9 Janice MacKinnon, "Is Equalization Broken? Can Equalization be Fixed?” (Fiscal Federalism and the Future of Canada, delivered at the Institute of Intergovernmental Relations, Queen's University, 28-29 September 2006), online: Institute for Intergovernmental Relations <http://www. queensu.ca/iigr/working/fiscalImb/MacKinnon. pdf $>$.

10 Stuart Landon \& Bradford G. Reid, “The Impact of the Centralization of Revenues and Expenditures on Growth Regional inequality and Inequality" 2005 Working Papers (2005) online: The Institute of Intergovernmental Relations <http://www.queensu.ca/iigr/working/archive/ pubwork2005/05landon.pdf $>$. 